\title{
Comunicació, ambigüitat i variació funcional. Una visió introductòria ${ }^{\mathbf{1}}$
}

\author{
Lluís Payrató \\ Departament de Filologia Catalana i Lingüística General, Universitat de \\ Barcelona
}

payrato@ub.edu

Recepció: 11/03/2021, acceptació: 18/04/2021

Resum: L'ambigüitat és un fenomen inherent a molts processos comunicatius, i comporta, en sentit estricte, una interpretació ambivalent d'un missatge; en sentit ampli es fa servir el terme també com a sinònim de «vaguetat». L'ambigüitat difereix especialment segons el registre o varietat funcional del llenguatge que es consideri: en l'article s'analitza el fenomen en relació amb el llenguatge corrent, el literari i els llenguatges d'especialitat (tecnolectes), i s'apunten diferents estratègies pragmàtiques i discursives que expliquen el perquè de les diferències.

Paraules clau: comunicació, ambigüitat, variació, registres, literatura, llenguatge corrent.

\section{Comunicación, ambigüedad y variación funcional. Una visión introductoria}

Resumen: La ambigüedad es un fenómeno inherente a muchos procesos comunicativos, y conlleva, en sentido estricto, una interpretación ambivalente de un mensaje; en sentido amplio, se usa el término también como sinónimo de «vaguedad». La ambigüedad difiere especialmente según el registro o variedad funcional del lenguaje que se considere: en el artículo se analiza el fenómeno en relación con el lenguaje corriente, el literario y los lenguajes de especialidad (tecnolectos), y se apuntan diferentes estrategias pragmáticas y discursivas que expliquen el porqué de las diferencias.

Palabras clave: comunicación, ambigüedad, variación, registros, literatura, lenguaje corriente

\section{Communication, ambiguity and functional variation: An introductory look}

Abstract: Ambiguity is a phenomenon inherent to many communicative processes, and involves, in a strict sense, an ambivalent interpretation of a message; in a broad sense, the term is also used as a synonym of "vagueness". Ambiguity differs especially according to the register or functional variety of the language being considered: in this paper, the

\footnotetext{
${ }^{1}$ Agraeixo als companys i companyes del GrEPAD els comentaris al voltant d'aquest article, que s'ha beneficiat dels ajuts PID2019-104453GA-Ioo i 2017SGR-942. 
phenomenon is analysed in relation to everyday language, literary language and specialist language (technolects), and various pragmatic and discursive strategies that explain the differences between these registers are noted.

Keywords: communication, ambiguity, variation, registers, literature, everyday language.

\section{INTRODUCCIÓ: COMUNICACIÓ, VARIACIÓ FUNCIONAL I AMBIGÜITAT}

L'ambigüitat - entesa, per començar, en un sentit corrent, ampli i general- és un fenomen que toca de ple el nucli dels processos comunicatius, entesos, al seu torn, com a processos de transmissió d'informació, de reconeixement d'intencions i de modificació recíproca de conductes en la interacció social. Així com el concepte tècnic de soroll en la teoria clàssica de la informació afecta sobretot el canal i la bona recepció del missatge, el concepte d'ambigüitat es planteja bàsicament en relació amb la (no) interpretació adequada, correcta i rellevant del missatge.

El fenomen de l'ambigüitat és també un dels que marca més diferències (i diferències més notables) en el domini de la variació funcional del llenguatge, també anomenada -amb altres termes més conflictius o ambigus, justament- contextual o estilística. En síntesi, mentre que en el llenguatge corrent - $\mathrm{i}$, en particular, en la conversa col-loquial, hàbitat "per defecte» de les llengües- poden produir-se malentesos ocasionals, però l'ambigüitat és prou ben controlada pels parlants - amb estratègies específiques- i el registre mateix admet un nivell de vaguetat alt, en el llenguatge literari l'ambigüitat sol ser (o pot ser) molt més elevada, perquè el text es presenta - ja de manera premeditadamolt més obert pel que fa a la seva interpretació. Finalment, com a tercer vèrtex d'un triangle imaginari, trobem el cas dels llenguatges d'especialitat, creats precisament amb la voluntat d'aconseguir una funció desambiguadora: la terminologia persegueix que s'estableixi una relació biunívoca entre termes i conceptes; dit a l'antiga i de manera molt planera: a cada cosa el seu nom, i un nom per a cada cosa.

Plantejar el com i el perquè de l'ambigüitat en el domini lingüístic i de la comunicació té un interès especial, tant en un sentit estrictament teòric com en un d'aplicat. En el primer, marca els límits i la capacitat semiòtica dels codis i de les facultats cognitives de les ments que elaboren i interpreten missatges. En el vessant aplicat, la reducció de l'ambigüitat és un objectiu prioritari, tant en qüestions més o menys (in)transcendents de la vida corrent (evitar malentesos quotidians en la conversa col-loquial) com en qüestions relatives a la transmissió d'informació en dominis tècnics o especialitzats, per exemple, en una operació quirúrgica o en les maniobres d'enlairament i aterrament en el transport aeronàutic. ${ }^{2}$

\section{SOBRE EL CONCEPTE I LA PARAULA CORRENT: L'AMBIGÜITAT DE L'AMBIGÜITAT}

\footnotetext{
${ }^{2}$ En el domini de la vida corrent, hem experimentat, recentment, la diferència entre els costums que teníem i haver d'interactuar amb una mascareta que cobreix una zona de la cara molt important per a l'expressió de les emocions. El canvi de certes convencions comunicatives i l'augment de l'ambigüitat i la incertesa o vaguetat és evident (vegeu-ne més detalls a l'article de Rubio 2020). En els dominis especialitzats, des de la medicina a l'aeronàutica, el valor d'una transmissió no ambigua de la informació és obvi i ben conegut. Per posar-ne un sol exemple, i ben tràgic, l'accident aeri més greu de la història (583 víctimes mortals), que va tenir lloc a l'aeroport de Tenerife (Los Rodeos) el març de 1977, va ser causat per un conjunt de factors complexos, i entre els més importants figuren les ambigüitats i els malentesos en els diàlegs entre les tripulacions de dos avions i els controladors de l'aeroport.
} 
Hi ha termes que reflecteixen el que són, i aquest és el cas de les paraules ambigu i ambigüitat, que són, almenys com a termes corrents, paraules ambigües, o si més no, vagues. Ho posa de manifest de seguida un cop d'ull al diccionari (DIEC, s. v.):

(1) ambigu -a

adj. [LC] [FLL] [FL] Que ofereix diferents sentits, que admet diferents interpretacions. Una resposta ambigua. Una expressió ambigua.

(2) ambigüitat

$11 f$. [LC] [FL] [FLL] Qualitat d'ambigu. L'ambigüitat de la seva resposta.

$12 f$. [LC] [FL] [FLL] Mot o expressió ambigus. Dona'm una resposta clara: no em vinguis amb ambigüitats.

$21 f$. [FL] ambigüitat lèxica Fenomen lingüístic que es dona quan es poden atribuir diversos significats a un mot en una oració.

22 [FL] ambigüitat sintàctica Fenomen lingüístic que es dona quan es poden assignar diverses descripcions estructurals, i en conseqüència, diverses interpretacions semàntiques, a una oració.

Dit, doncs, de manera entenedora i senzilla, un terme ambigu o una expressió ambigua té «diferents sentits» o «admet diferents interpretacions»: una paraula per a diferents «coses», o una expressió amb diferents «significats». Pot servir de perfecte i curiós exemple el mateix mot ambigú, procedent del francès (DIEC):

(3) ambigú [pl. -ús]

$1 \mathrm{~m}$. [LC] Âpat fred en què se serveixen tots els plats alhora.

$2 \mathrm{~m}$. [LC] Apartament d'un teatre on se serveixen aquests àpats.

L'àpat ambigú (perquè no hi ha ordre en els plats, se suposa; se servien alhora carns i postres) dona pas, per metonímia (el lloc pel fenomen que s'hi dona), a la part del teatre on es fa l'àpat ( 0 , com en castellà, al moble, com a sinònim de bufé). Es tracta d'un gal-licisme que procedeix d'ambigu, mot que, al seu torn, com el corresponent a altres llengües romàniques, és «pres del ll. ambiguus id., derivat de ambigere 'estar en discussió', i aquest de agere 'conduir' amb prefix amb- 'entorn'» (DECat, s. v.).

Com a sinònims actuals d'ambigu se solen fer servir els termes ambivalent, equívoc, vague, inconcret, incert, etc. Tant en aquests sinònims com en les definicions i exemples anteriors s'endevina ja de bon començament una duplicitat força clara dels sentits corrents, que es mostra de manera més evident en la definició del terme castellà del diccionari de la RAE:

(4) ambiguo, gua Del lat. ambiguus.

1. adj. Dicho especialmente del lenguaje: Que puede entenderse de varios modos o admitir distintas interpretaciones $\mathrm{y}$ dar, por consiguiente, motivo a dudas, incertidumbre o confusión.

2. adj. Dicho de una persona: Que, con sus palabras o comportamiento, vela o no define claramente sus actitudes u opiniones.

3. adj. Incierto, dudoso.

Es tracta, doncs, de concebre l'ambigüitat com a amfibologia (expressió amb dos o més sentits, però no pas vaga ni vagues) i l'ambigüitat com a vaguetat (és a dir, ara sí, no-claredat, imprecisió o indeterminació, poca especificació). La primera d'aquestes dues alternatives és la que queda recollida en les accepcions anteriors 2 i 3, sota les subentrades ambigüitat lèxica i ambigüitat sintàctica, respectivament, i això ens fa entrar ja en l'anàlisi del terme ambigüitat en el domini de les ciències del llenguatge. La 
segona alternativa, per cert, o sigui, l'ambigüitat entesa com a vaguetat, no sol ser reconeguda amb el nom d'ambigüitat en aquest domini especialitzat, i se solen fer servir termes com indeterminació o subespecificació.

\section{El TERME TÈCNIC: L’AMBigÜITAT EN LINGÜÍSTICA}

La duplicitat que s'acaba d'apuntar per al mot corrent se simplifica, d'una banda, i es fa més complexa, d'una altra, en el cas del mot tècnic, del tecnicisme (el mot considerat en un llenguatge d'especialitat).

En les accepcions 2 i 3 de la definició anterior del DIEC es presenta una altra duplicitat molt marcada: l'ambigüitat lèxica versus la sintàctica. En la primera trobem dos dels fenòmens més analitzats en els estudis lingüístics: la polisèmia, o sigui, el fet que una paraula tingui més d'un sentit (per exemple, nou o gat), i l'homonímia, o sigui, el fet que dues o més paraules de diferent procedència i significat coincideixen en el so i en la grafia (homòfones i homògrafes, com sol i sol, referides a l'astre o a la solitud), només en el so (homòfones: ham i $a m b$-en català occidental-) o només en la grafia (homògrafes: venen, de venir o de vendre, amb la vocal tònica tancada o oberta; rave, com a terme genuí o com a anglicisme). En canvi, en el segon cas, el de l'ambigüitat sintàctica, trobem estructures sintàctiques i interpretacions semàntiques diferents: Va agafar la gossa amb el llacet o Van pujar per l'escala amb flors, per exemple.

Però aquests coneguts casos de l'ambigüitat lingüística no són els únics que es poden trobar, sobretot si es refina l'anàlisi. Comparem la definició anterior del diccionari normatiu amb la d'un diccionari tècnic o especialitzat, per exemple, el de Pérez Saldanya et al. (1988: s. v.), i ens adonarem que, per començar, la diferència és mínima:

(5) ambigüitat Fenomen segons el qual una determinada manifestació lingüística admet diferents interpretacions.

Tanmateix, el diccionari tècnic sí que va molt més enllà a l'hora d'especificar en subentrades les diferents subclasses del fenomen (exposades a continuació de manera reduïda, i amb els exemples originals) ${ }^{3}$ :

(6) D'acord amb el nivell en què es produeix l'ambigüitat, es pot parlar d'ambigüitat fonològica, morfològica, lèxica, estructural, temàtica, referencial i d'abast o lògica. [...]

ambigüitat d'abast Fenomen pel qual una oració amb dos o més quantificadors o operadors pot assolir interpretacions diferents segons el domini d'aplicació de cada quantificador o operador. [(Per exemple Tots els meus amics estimen una xica)...]

ambigüitat estructural Fenomen pel qual estructures sintagmàtiques diferents poden coincidir en l'ordre lineal dels seus elements. [(Per exemple els amics de l'Antoni i la Maria)...]

ambigüitat fonològica Fenomen pel qual una estructura fonològica és susceptible

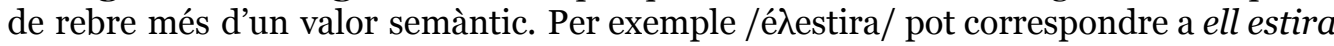
o a ell es tira. [...]

ambigüitat lèxica Fenomen pel qual un mateix significant lèxic, per causes d’homonímia o de polisèmia, pot associar-se a diferents significats. [(Per exemple el mot banc)...]

\footnotetext{
${ }^{3}$ Una presentació especialitzada més extensa i aprofundida es troba a Sennet (2016). En un capítol per a una enciclopèdia de filosofia, aquest autor fa una anàlisi molt detallada de tots els sentits que té el terme ambigüitat, i els compara, a més a més, amb fenòmens similars però que no considera, en termes tècnics, pròpiament ambigüitats (bàsicament, vaguetats, sentits genèrics i indeterminacions).
} 
ambigüitat morfològica Fenomen pel qual diferents elements d'un paradigma adopten una forma idèntica. [(Per exemple cantem, indicatiu o subjuntiu)...]

ambigüitat referencial Fenomen pel qual un únic pronom pot tenir diferents antecedents. [(Per exemple Emili digué que ell no assistiria a la reunió)...]

ambigüitat temàtica Fenomen pel qual un mateix argument pot rebre papers semàntics diferents en una mateixa construcció. [(Per exemple la invitació de Roser) ...]

Al marge de les precisions més o menys tècniques dels diccionaris de lingüística, en últim terme es fa evident que, més enllà d'intentar establir una tipologia o una categorització precisa de l'ambigüitat, la descripció i l'explicació del fenomen dependrà al capdavall de la teoria lingüística que utilitzem i que tinguem com a marc de referència, amb els seus pressupòsits, les seves bases i la seva terminologia.

\section{L'AMBigüITAT EN EL LLENGUATGE CORRENT}

Tots aquests fenòmens que acabem de repassar es poden donar en el que solem anomenar «llenguatge corrent». De fet, quan es parla d'ambigüitat de manera descontextualitzada podem pensar que implícitament sempre s'hi troba aquest concepte, al darrere. Ara bé, resulta obvi que no es pot caure en generalitzacions o apreciacions massa vagues en referència a conceptes que al seu torn són massa amplis o indeterminats, com aquest mateix de «llenguatge corrent», aplicable a la llengua oral, però també a l'escrita; a l'espontània, però també a la preparada o planificada (en diferents graus); a la més o menys (in)formal, a la informativa, però també a la interactiva, etcètera.

En un sentit més restringit, podem convenir, d'entrada, que quan parlem de llenguatge corrent ens referim per defecte a la varietat col-loquial, definible com un registre prototípicament oral, no planificat, interactiu, informal i de tema no especialitzat (Payrató 1996). En qualsevol cas, la resposta a la pregunta de quin és el nivell permissible d'ambigüitat en aquest registre -0 , millor, en aquest conjunt de registres- no es pot contestar de manera immediata i senzilla, i la primera matisació és que depèn molt del context i dels subregistres (o subllenguatges) a què ens referim.

Des de la lingüística tradicional s'ha tendit sovint a dir -o almenys a suggerir-que la llengua escrita és més precisa que l'oral. Amb l'avinentesa del que s'acaba de recordar del perill de les generalitzacions, podem convenir que és així, per bé que d'aquí no es desprèn que l'oralitat sigui més ambigua per se que el domini escrit, igual que no és més informal, necessàriament. Si de cas, hauríem de dir que el que tendim a imaginar com a mostra prototípica de l'oral (la conversa espontània, col-loquial) és més vaga (o indeterminada) que l'escrit prototípic (expositiu, planificat i formal).

Resulta arriscat anar més enllà d'afirmacions tan matisades com aquesta sense concretar textos i contextos. Un exemple prou il-lustrador el trobem en el cas del díctic català aquí. En molts dialectes s'oposa només a allà (o allí) i, per tant, és susceptible, $a$ priori, de causar ambigüitats, per tal com neutralitza l'oposició entre l'espai del jo i del tu, d'una banda, i la distingeix només de l'espai llunyà -el «d'altres»-, de l'altra; sí que hi ha separació en tres graus en altres dialectes (aquí, ací, allí/allà), o bé en castellà (aquí, ahí, allí/allá). En una conversa telefònica, posem per cas, podríem predir que hi ha d'haver un fort risc d'ambigüitat, atès que els dos interlocutors comparteixen la forma referida al jo, però no pas l'espai real. Tanmateix, el fet és que no se sol produir cap problema perquè contextualment -cotextualment, amb el text que envolta la forma- se soluciona el risc de malentès. Els parlants són prou competents com per fer servir estratègies de clarificació - per evitar possibles malentesos- o de reparació, si creuen que s'ha produït alguna disfunció en la interpretació. Així, per exemple, en relació amb l'exemple apuntat, parlar 
d'aquí (per a l'espai del jo) enfront d'aquí dalt o aquí on ets (per a l'espai del tu); o, en castellà, en el cas dels possessius, referir-se a su madre de usted (amb qui s'està parlant) en lloc de a su madre (d'una tercera persona) per evitar l'homonímia.

Es podrien afegir molts més exemples en aquesta línia, però, en síntesi, tot apuntaria al fet que el registre corrent es regula perfectament - per bé que amb diferències segons els subregistres i estils- per evitar l'ambigüitat. Igual que el flux conversacional (interactiu/il-locutiu alhora, amb canvis de torn i actes de parla successius) evita els silencis i els recobriments (o solapaments), o, en tot cas, els redueix a un percentatge ínfim, el flux informatiu es preserva perfectament (a grans trets) de possibles interferències negatives i d'amfibologies. Mentre que, si ens mirem les possibilitats o potencialitats del sistema, l'ambigüitat sembla que s'hagi de produir molt sovint, gairebé que sigui inevitable, quan comprovem la realitat de l'ús trobem més aviat el fenomen contrari: la poca incidència de l'ambigüitat. Així ho han corroborat, de fet, les percepcions dels analistes conversacionals (des de l'etnometodologia, sobretot), i en especial Emanuel Schegloff:

Most theoretically or heuristically conjurable ambiguities never actually arise. That could be so because of the operations of a so-called disambiguator, as a component of the brain, as a service of context to syntax, and so on. Or it could be that the theoretically depictable ambiguities are derived by procedures that are not relevant to naturally occurring interaction, and therefore in natural contexts the ambiguities are not there to disambiguate. (Schegloff 1984: 50)

Segons Schegloff, les ambigüitats en la conversa venen, si de cas, de l'organització seqüencial, però no són les típiques ambigüitats «teòriques», o sigui les de frases aïllades fora d'un context determinat (com ara els exemples apuntats més amunt, a l'apartat precedent). No es tracta de defugir el problema ni de menysprear-lo, sinó de fer veure que estem tocant, en el fons, dues qüestions diferents, i que, en definitiva, l'ambigüitat conversacional -que podríem ampliar a tots els registres del llenguatge «corrent»- té ben poc a veure amb la hipotètica i teòrica ambigüitat del sistema:

I mean only to suggest that the study of such theoretical ambiguity needs to be distinguished from the sort of ambiguity that actual conversationalists actually, empirically encounter as ambiguities in the natural course of conversation. (Schegloff 1984: 51)

Aquesta línia porta a pensar també en la concepció filosòfica ja proposada per Ludwig Wittgenstein (1953), en el sentit de recalcar que, en el llenguatge ordinari (corrent), tot sembla realment que estigui en ordre. De fet, si hi reflexionem des d'una perspectiva evolucionista, per què i com no hauria de ser així? Un codi desenvolupat des de fa milions d'anys ha de tenir un nivell d'eficàcia molt alt, sobretot tenint en compte la importància de les seves funcions, tant des d'un punt de vista ontogenètic com filogenètic, és a dir, tant per a l'individu en particular com per a l'espècie en conjunt. Per tant, l'ambigüitat pot aparèixer, però té molt poca cabuda i ressonància en el llenguatge corrent... tret que sigui intencionada, deliberada, però aleshores solem estar davant d'un canvi de registre (cap al literari) o davant la transgressió - per les raons que sigui- de les normes o màximes conversacionals que seguim habitualment, tal com va proposar al segle passat el també filòsof H. Paul Grice (1975).

En efecte, en el plantejament de Grice, prou conegut, el principi de cooperació estableix que participem de manera positiva en els intercanvis verbals, segons l'estadi en què es troben, perquè es desenvolupin adequadament, i això ho fem seguint quatre 
màximes conversacionals: la de qualitat $\mathrm{o}$ veritat (dir el que és cert, no dir allò de què no tenim proves o que sabem que és fals), la de quantitat (donar un grau d'informació just, ni més alt ni més baix del que convé), la de relació (donar informació pertinent o rellevant) i la de manera (donar la informació d'una manera ordenada, clara, no prolixa). Aquesta última màxima estableix justament que hem de limitar l'ambigüitat en els nostres intercanvis, i a la pràctica s'aparella amb la de quantitat: donar la informació que cal, ni més ni menys. Vist així, amb aquesta perspectiva normativitzadora, l'ambigüitat només és permissible - i es dona habitualment- quan transgredint la màxima de manera s'aconsegueix un efecte significatiu addicional, és a dir, es fa el que Grice bateja com a implicatura: vehicular informació addicional a la literal, comunicar al marge -a més a més- del que es diu. Fora d'aquest cas, en fi, l'ambigüitat sembla més pròpia dels registres literaris que de cap altre àmbit.

\section{L'AMBIGÜITAT EN EL LLENGUATGE LITERARI}

El registre col-loquial ha estat anomenat sovint -tot i que de manera prou desencertada-familiar, sobretot en l'àmbit de la lingüística romànica, i malgrat que Joan Coromines (DECat, s. v. col-loquial) ja desaconsella l'ús d'aquest terme. En canvi, s'ha parlat sovint, precisament, de la desfamiliarització com una de les estratègies bàsiques del registre literari: un mirar no automatitzat ni mecànic cap a la vida ordinària, corrent. A aquesta circumstància hi hem de sumar una voluntat estètica que recorre a múltiples, variats i innovadors recursos estilístics que, al seu torn, comporten una elaboració o treball sobre el missatge (la coneguda funció poètica de Roman Jakobson) molt superior -incomparable, en general- al que trobem en altres registres, inclòs el col-loquial, tot i que sigui el que més s'hi acosta.

Com en els altres casos, però segurament ara d'una manera més evident, el sintagma llenguatge literari s'hauria de reconvertir i d'entendre ja de bon principi com a llenguatges literaris. Si en algun domini es fa palesa la diversitat estilística, és en aquest, i per això l'estilística - com a disciplina d'estudi- ha estat durant tant de temps, tradicionalment, una estilística literària més que no pas una estilística funcional, pragmàtica (o pragmaestilística) o - com ho és des de fa molt poc- una estilística cognitiva.

El grau d'ambigüitat dels registres literaris no està associat a la qualitat estètica o literària de l'obra (i als cànons corresponents), sinó al (sub)gènere i als estils específics dels autors. En aquest últim cas, per exemple, les diferències entre el trobar clus, ric i lleu dels trobadors provençals, o els biaixos conceptistes i culteranistes de la poesia del Segle d'Or espanyol podrien ser mostres de grans tendències en relació amb les formes d'expressió que afecten, si més no indirectament, l'ambigüitat. Pel que fa als (sub)gèneres, la poesia lírica intimista o el teatre de l'absurd es poden permetre uns nivells d'ambigüitat que no esperaríem en una novel-la històrica o en un assaig.

Segurament, el grau màxim d'ambigüitat en els registres literaris s'aconsegueix quan el treball sobre el missatge porta a la creació de textos que només poden ser interpretats per connotacions o similituds. La invenció de paraules (respectant les regles de formació de mots) i la seva combinació amb altres de corrents s'ha donat en obres molt conegudes, i amb unes consegüents interpretacions força variades. Continuant amb exemples del gènere poètic, probablement la més famosa d'aquestes composicions és «Jabberwocky», poema de Lewis Carroll inclòs a l'obra Through the Looking Glass (1871), segona part de Alice's Adventures in Wonderland (1865). El poema va ser traduït al català primer per Amadeu Viana: «El Barboteixot», dins A través de l'espill (Barcelona: Quaderns Crema, 1985). Més tard, per Víctor Compta (dins Les aventures d'Alícia, Barcelona: Barcanova, 
1990) i per Salvador Oliva («Xerrapetaire», dins A través del mirall i allò que Alícia hi va trobar, Barcelona: Edicions 62, 2012). Viana en va fer una segona versió l'any 1998 («Xerramiquera», cf. Viana 1998). Al castellà va ser traduït per primer cop per Marià Manent («El Dragobán», dins En el mundo del espejo, Barcelona: Juventud, 1944). Començant ja pel títol del poema -i per posar un primer exemple-, la comparació dels textos traduïts amb l'original és un exercici excel-lent per veure com cada un dels traductors s'enfronta amb el problema de traduir, al costat de paraules reals, paraules inventades i amb uns sentits (o amb uns "sense sentit») connotats, suggerits. ${ }^{4}$ Quedi com una breu mostra la primera estrofa de les traduccions de Viana $(1985,1998)$ i d'Oliva (2012), en què es pot comprovar que no hi ha ni una sola paraula comuna:

(7) «Jabberwocky» (Lewis Carroll, 1873)

'Twas brillig, and the slithy toves Did gyre and gimble in the wabe; All mimsy were the borogoves, And the mome raths outgrabe.

(8) «El Barboteixot» (Viana, 1985)

Era temps brillós: les eslludentes tolves girclaven varrinant en les onacles; assats mimayres eron los borogovis, e.l bormi ratins abrisanava.

(9) «Xerramiquera» (Viana, 1998)

Dens era dens quan la brova fircant gorsava i esmeia en la drana. Tot ho imutava la sardatxana i anardava les grates lo lutant.

(10) «Xerrapetaire» (Oliva, 2012)

Rostillejava, i l'actillís teixó giroscava furant pel gesperbatge el misfluix era com un papaó. I els pers xiublaven a l'escatge.

En castellà hi ha molts exemples també del que s'ha acabat anomenant jitanjáfora, mot que fins i tot ha passat a formar part del diccionari de la RAE:

(11) jitanjáfora. (Palabra inventada por el humanista mexicano Alfonso Reyes, 1889-1959). f. Enunciado carente de sentido que pretende conseguir resultados eufónicos. ${ }^{5}$

En fragments de prosa, un dels més coneguts és l'escrit en «gíglic» per Julio Cortázar a Rayuela (1963), que comença amb l'enunciat següent: «Apenas él le amalaba el noema, a

\footnotetext{
${ }^{4}$ L'exercici no es pot dur a terme, òbviament, en aquestes pàgines, per qüestions d'espai. Vegeu, en especial, l'estudi de López Guix (2017), sobre dotze traduccions al castellà.

${ }^{5}$ Dubto que la definició sigui gaire afortunada, perquè aquests enunciats solen suggerir alguna cosa més que un bon so. I l'etimologia encara ho és menys, perquè el terme és original d'un poema d'Antonio Brull, poeta cubà descendent de catalans, que va recollir Reyes.
} 
ella se le agolpaba el clémiso y caían en hidromurias, en salvajes ambonios, en sustalos exasperantes». Si en el cas del «Jabberwocky» la connotació és la de vèncer una bèstia monstruosa (el «Jabberwock»), en aquest cas és prou evident que s'entreveu una trobada amorosa.

A banda d'aquests casos d'obres breus, fins i tot el sentit general o global de tota una obra literària pot ser també ambigu. Encara que sigui per esmentar també un sol cas, una de les que ha dut a més interpretacions i discussions és la narració «The Figure in the Carpet» (1896), de Henry James, que pot ser interpretada, bàsicament, a partir d'una lectura irònica o no irònica; en l'estudi de Popova (2002) es pot comprovar com l'estilística cognitiva pot ajudar a analitzar l'ambigüitat.

La ironia, el sarcasme, la hipèrbole, els dobles sentits... enfront de la literalitat: dues dimensions que conviden a l'ambigüitat, que connecten el llenguatge literari amb el llenguatge col-loquial, i que, en canvi, no apareixen en absolut en el tercer vèrtex d'aquestes comparacions, el dels registres tècnics o especialitzats.

\section{L'AMBIGÜITAT EN ELS LLENGUATGES D’ESPECIALITAT}

A diferència de l'àmbit del registre corrent, i sobretot dels registres literaris, on és molt habitual, en els llenguatges d'especialitat l'ambigüitat no hi ha d'aparèixer per definició. En efecte, i dit a la manera tradicional, com s'avançava a l'inici en relació amb la polisèmia i l'homonímia, un llenguatge d'especialitat (o llengua especialitzada, o registre tècnic o tecnolecte $)^{6}$ neix per promoure una comunicació eficaç, no ambigua, amb un tractament objectiu -no subjectiu, sinó impersonal- de la informació, i on no apareguin ni la polisèmia ni l'homonímia; per tant, dit a la manera clàssica, un mot per a cada cosa i a cada cosa el seu mot: una correspondència biunívoca que, si no pot ser perfecta, com a mínim ha de ser l'ideal que es persegueix.

La diferència dels registres tècnics amb els registres anteriors és també una diferència d'usuaris: mentre que en els dos casos precedents parlem del conjunt de la comunitat de parla, en el cas dels llenguatges d'especialitat, tant si els concebem de manera unitària («el» registre especialitzat) com si els entenem diversificats («els» registres especialitzats), els usuaris són un subconjunt clar de la comunitat: els professionals d'aquest sector, no pas els parlants corrents. Qualsevol dels fenòmens d'ambigüitat o vaguetat apuntats al llarg de l'apartat 3 es podrien trobar -teòricament, hipotèticamenten el llenguatge corrent. En canvi, és molt difícil imaginar contextos on podríem trobar ambigüitats respecte de termes com els següents, definits tan tècnicament i tan formalment que no semblen ni tan sols gaire aptes per ser recollits als diccionaris no especialitzats d'una llengua:

(12) zooxantel.la $f$. Alga de la classe dels dinòfits, de vida endocel.lular, que estableix una simbiosi amb diversos animals marins. (DIEC, s. v.)

(13) 4109 àcid propiònic Àcid monocarboxílic saturat de fórmula $\mathrm{CH}_{3} \mathrm{CH}_{2} \mathrm{COOH}$.[...] 4117 àcid sacàric Àcid dicarboxílic de fórmula $\mathrm{HOOC}(\mathrm{CHOH})_{4} \mathrm{COOH}$, que es forma per oxidació de les hexoses. (DIEC, s. v. àcid)

\footnotetext{
${ }^{6}$ No es fan matisos entre aquests termes ni es distingeix tampoc, a efectes de simplificar l'exposició, entre llenguatges d'especialitat (que entenem com a registres tècnics i científics) i usos lingüístics amb finalitats específiques (a mig camí entre els anteriors i el llenguatge corrent). Vegeu, sobre aquesta qüestió, Cabré (2004). Un altre concepte equivalent als anteriors és el de subllenguatge, molt utilitzat en lingüística computacional i de corpus (vegeu López Sanjuán 2007).
} 
(14) trifosfopiridina-nucleòtid $m$ BIOQ Nicotinamida-adenina-dinucleòtid-fosfat. (GDLC, s. v.)

(15) desoxiribonucleic-polimerasa $f$ BIOQ Enzim que catalitza la duplicació o síntesi de l'àcid desoxiribonucleic (ADN) a partir d'una mescla de 5'-trifosfats [sic!] dels seus quatre desoxiribonucleòsids com a precursors. (GDLC, s. v.)

(16) 1,1,2,2-tetrabromoetà $m$ QUIM ORG [BR2CH-CHBR2] Líquid groguenc, obtingut per tractament de l'acetilè amb brom i posterior rectificació, emprat com a solvent de greixos, olis i ceres. (GDLC, s. v.)

No trobem en els dominis dels tecnolectes, per consegüent, els fenòmens d'ambigüitats que hem vist en els apartats anteriors, i en principi s'eviten igualment els fenòmens similars que Sennet (2016) no qualifica pròpiament d'ambigüitat però que descriu com a similars o pròxims. Només en el cas que es busqués - de manera deliberada- la generalitat o la indeterminació, seria permissible aleshores l'ambigüitat; per exemple, posem per cas, en el llenguatge jurídic quan es pretén que la interpretació que es farà d'una norma sigui precisament no marcada, i s'admet, d'entrada, que l'acabaran fixant les convencions socials de la comunitat on s'aplicarà, o bé les normes d'abast inferior que més endavant la desenvoluparan i concretaran.

A la inversa, l'excés de tecnicismes sol ser evitat en el llenguatge corrent. El llibre d'estil de la Corporació Catalana de Mitjans Audiovisuals, per exemple, aconsella no vehicular enunciats del tipus El jugador té una tendinopatia al vast extern del genoll esquerre, i afegeix que és preferible decantar-se per enunciats com El jugador té una lesió en un tendó del genoll esquerre..$^{7}$ A la inversa, no cal dir que el segon enunciat no seria adequat en un context especialitzat de professionals de la medicina esportiva.

El límit d'aquesta recerca de la «no-ambigüitat» (dit en terme negatiu) el posa la formalització, el recurs a una simbologia o notació i un llenguatge formal. És el cas, per exemple, de l'ambigüitat en el llenguatge corrent d'un connector com la conjunció $o$, que pot interpretar-se de manera conjuntiva o disjuntiva (exclusiva): Li agraden les pel-lícules o les sèries pot voler dir que a algú li agraden totes dues coses -la conjunció $o$ equival aleshores a $i-$, o bé només una de les dues (interpretació disjuntiva). Aquesta ambigüitat no es dona quan s'utilitzen operadors lògics, de manera que $\wedge$ vol dir sempre ' $\mathrm{i}$ ' (conjuntiu inclusiu) i $\vee$ vol dir 'o' (exclusiu). L'extensió recent en alguns registres de l'ús de la fórmula $i / o$ té aquesta explicació i aparent justificació, per bé que en sentit estricte (i lògic) no caldria, perquè justament $o$ té sempre la interpretació doble. Si no es vol córrer el perill de malentesos, es pot fer explícit amb altres estratègies. Així és com soluciona la qüestió el Llibre d'estil de les lleis $i$ altres textos del Parlament de Catalunya (pàg. $134-135): 8$

(17) La combinació de conjuncions amb la barra inclinada (i/o) crea ambigüitat i inconcreció. S'ha de substituir per una conjunció o per l'altra, segons que es vulgui remarcar una relació d'alternativa $(o)$ o d'addició (i) entre els diversos elements. corporació.

$\sim$ Un terç ha d'ésser integrat per membres i/o funcionaris de la mateixa

\footnotetext{
${ }^{7}$ Vegeu <https://www.ccma.cat/llibredestil/manual-dus/tecnicismes-i-altres-paraules-dus-restringit $>$.

${ }^{8} \mathrm{La}$ intenció dels usuaris de la combinació i/o és remarcar que l'expressió es pot entendre en els dos sentits (cosa que ja passa sempre amb $o$, encara que els emissors i/o receptors potser no en siguin conscients). Per això, l'últim exemple és igual que si digués «del llenguatge mímic o de subtitulacions». Afegir-hi «o ambdós» o «tots dos» hi dona, això sí, un caràcter més explícit i/o entenedor.
} 
$\checkmark$ Un terç ha d'ésser integrat per membres o funcionaris de la mateixa corporació.

$\sim$ pel que fa als usos turístics i/o esportius

v pel que fa als usos turístics i als esportius

Si es vol remarcar que tant pot ésser qualsevol de les dues opcions com ambdues alhora, es pot indicar de manera explícita.

per mitjà de l'ús del llenguatge mímic i/o subtitulacions

alhora

v per mitjà de l'ús del llenguatge mímic, de subtitulacions o d'ambdós recursos

Les confusions poden venir a vegades de qüestions interculturals relacionades amb la traducció i els anomenats falsos amics. Per exemple, un billion és un miler de milions en anglès, però un bilió és un milió de milions en català (trillion, en anglès). Lògicament, aquest tipus de confusió no es dona tampoc en llenguatges formals, i, en tot cas, aquesta mena d'exemples ens porta -més que a l'ambigüitat pròpiament dita- als errors (fruit d'estratègies de generalització o simplificació en l'aprenentatge) i a les interferències (fruit de la influència entre llengües).

Dins del gran domini de la variació funcional, no s'ha d'entendre tampoc que en les llengües d'especialitat el grau de variació sigui el zero absolut, sinó més aviat que qualsevol tipus de variació es controla molt més que en el registre corrent, i sobretot que en els registres literaris. En el discurs acadèmic, per exemple, s'hi han pogut reconèixer tradicionalment diferents estils, alguns més aviat romànics o anglosaxons (posem per cas en la manera de fer un abstract, o d'estructurar una comunicació o una ponència en un congrés). No hi ha tampoc un sol model de pòster o de comunicació oral, en els congressos, ni en l'estructura ni en l'estil. Encara que sembla evident que en general els patrons anglosaxons es van imposant progressivament, les diferències culturals en aquest domini seria lògic que es reivindiquessin -0 , si més no, que no es discriminessin-; al capdavall, representen una mostra de diversitat que no posa pas en perill la fiabilitat i l'adequació de la creació i transmissió de coneixement.

\section{Cloenda. Ambigüitat i variació funcional}

Els tres casos analitzats mostren un tractament ben diferenciat del fenomen de l'ambigüitat. Evidentment, hi ha altres registres, però hi trobaríem, segurament, tendències i característiques molt similars a les analitzades en els tres casos prototípics. D'una altra banda, tant en aquest altres registres com en subregistres englobables en els respectius àmbits comentats, les diferències poden tenir a veure amb l'estil particular de qui produeix el text. En últim terme, la variació funcional és sempre gradual, i en general els registres no se separen - tret del cas d'una part del lèxic- de manera categòrica: comparteixen molts aspectes dels diversos nivells lingüístics, i en especial recursos sintàctics i, en la llengua oral, prosòdics.

Més productiu resulta, a fi de tenir una visió final general del fenomen de l'ambigüitat i la variació funcional, repassar la relació d'aquest fenomen amb els factors bàsics de la variació funcional (camp, mode, tenor i to, seguint una aproximació tradicional ${ }^{9}$ ), i adonar-nos de quines correlacions solen donar-s'hi:

\footnotetext{
${ }^{9}$ Vegeu Payrató (2010) pel que fa als orígens i desenvolupament d'aquesta concepció i consegüent classificació, amb arrels a la lingüística funcional anglosaxona (en especial, en l'obra de M. A. K. Halliday; vegeu Halliday 1978).
}

Comunicació, ambigüitat i variació funcional. Una visió introductòria Lluís Payrató (2021)

Llengua, Societat i Comunicació, núm. $19 \quad$ http://revistes.ub/index.php/LSC/

lsc@ub.edu http://creativecommons.org/licenses/by-nc-nd/4.o doi:10.1344/LSC-2021.19.2 
(1) Camp: el camp o conjunt de temes tècnics o especialitzats busca evitar l'ambigüitat, mentre que el camp no especialitzat (corrent, comú), si més no, la tolera, o en tot cas l'evita gràcies al cotext (lingüístic) i al context (informatiu i situacional general).

(2) Mode: l'oralitat inclou ambigüitats (i indeterminacions) que no es donen en el domini escrit, sobretot si es espontània (per exemple en molts casos d'implicatura); el mode escrit preparat (planificat) és el que permet evitar amb més facilitat els fenòmens d'ambigüitat i vaguetat.

(3) Tenor: el tenor interactiu, sobretot si es combina amb el mode improvisat, s'associa amb un alt més grau d'ambigüitat que el tenor informatiu. El tenor interactiu de l'oralitat espontània s'associa amb fenòmens multimodals més complexos i significatius que els de l'escrit.

(4) To: la formalitat, en la mesura que implica una monitorització o control alt o molt alt del missatge, tendeix a evitar l'ambigüitat, si més no en contrast amb la informalitat (i sobretot si aquesta s'associa amb la interactivitat i la improvisació).

Si ens regim finalment pels principis de la retòrica textual que Leech (1983) va reformular a partir de treballs de Leonard Talmy, pensats per explicar l'evolució lingüística històrica però també altres fenòmens, podríem establir una taula amb la següent configuració: ${ }^{10}$

TAULA 1. Tipus de registres i principis pragmàtics

\begin{tabular}{cccc}
$\begin{array}{c}\text { Principi } \\
\text { pragmàtic }\end{array}$ & $\begin{array}{c}\text { Llenguatge } \\
\text { corrent }\end{array}$ & $\begin{array}{c}\text { Llenguatge } \\
\text { literari }\end{array}$ & $\begin{array}{c}\text { Llenguatges } \\
\text { d'especialitat }\end{array}$ \\
\hline processabilitat & $+/-$ & - & ++ \\
claredat & $+/-$ & - & ++ \\
economia & - & - & ++ \\
expressivitat & + & ++ & -
\end{tabular}

La variació funcional és gradual i presenta una casuística extraordinàriament complexa, molt variada i híbrida, però si llegim el quadre d'una manera senzilla i amb l'avinentesa que estem parlant de casos prototípics, la parla corrent (amb la conversa com a registre nuclear) no presentaria cap estratègia especial per afavorir l'economia $i$, en canvi, sí que en presentaria moltes per afavorir l'expressivitat. En això coincideix plenament amb el llenguatge literari, per bé que en el grau trobaríem en aquest últim molt més èmfasi en l'expressivitat (entesa, lato sensu, com a elaboració estètica del producte). La diferència bàsica entre els dos registres pel que fa a les estratègies ve, precisament, de la preocupació més gran, en el registre corrent, per aconseguir un grau més alt de processabilitat i claredat que en el registre literari. $\mathrm{Al}$ seu torn, aquestes dues estratègies, sumades a les de recerca de l'economia lingüística, són les predominants en

\footnotetext{
${ }^{10}$ Els quatre principis apuntats de Leech formen el que ell denomina la «retòrica textual», que es completa amb els principis de la «retòrica interpersonal» (on retrobem, en el nivell més alt, el principi de cooperació de Grice amb les quatre màximes esmentades i un principi de cortesia que proposa Leech). En una interpretació i exposició encara més sintètica, els principis de processabilitat i claredat es podrien presentar de manera conjunta (amb un abast similar al de la màxima de manera de Grice). En la proposta de Leech els principis i les màximes són d'aplicació gradual i cultural.
} 
els llenguatges d'especialitat. Vist així, la comunicació especialitzada (prototípica) vetlla sobretot perquè la informació transmesa sigui entenedora i arribi en les millors condicions per fer-ne una interpretació no ambigua: clara i precisa.

Òbviament, totes les anàlisis genèriques poden contenir un punt de simplisme, però és el peatge d'una visió panoràmica. Quan s'entra en casos particulars, cal valorar amb tota la complexitat possible cada exemple (cada «microanàlisi»), i així mateix les combinacions que es donin entre les estratègies, conseqüència de les intencions comunicatives específiques dels emissors, d'una banda, i fruit dels processos d'interpretació que duguin a terme els receptors, d'una altra.

En definitiva, i com a conclusió, es fa evident que, com en molts altres fenòmens relatius a l'ús lingüístic, el paper de l'ambigüitat està íntimament relacionat alhora amb l'estructura del llenguatge i amb les condicions contextuals d'emissió/producció i de recepció/interpretació dels missatges per part dels interlocutors. A cada registre, un grau (i, si de cas, un tipus d'ambigüitat), i un grau i un tipus per a cada registre. Encara que a vegades es digui que en la teoria de la variació funcional es recorre a argumentacions circulars, el fet és que els àmbits d'ús lingüístic i els registres (amb els trets que els caracteritzen) mostren una relació anàloga a la dels hàbitats i les espècies. Aquesta és una relació - una interrelació- que l'anomenada «ecologia del llenguatge» (vegeu, per exemple, Eliasson 2015) o la tradicional «etnografia de la comunicació» (Saville Troike 2002) ja han destacat molts cops i des de fa molts anys, i que també es podria concebre i donar com a mostra del que avui es consideren sistemes complexos.

\section{REFERÈNCIES BibLIOGRÀFIQUES}

CABRÉ, M. TERESA (2004): “¿Lenguajes especializados o lenguajes para propósitos específicos?”. Foro Hispánico: Revista Hispánica de Flandes y Holanda 26, 19-33.

Coromines, JoAn (1980-1987): Diccionari etimològic i complementari de la llengua catalana. Barcelona: Curial (esmentat com DECat).

Diccionari de la llengua catalana. Institut d'Estudis Catalans (2a ed., 2007, esmentat com DIEC).

Diccionario de la lengua española. Real Academia Española (23a ed., 2014, esmentat com DRAE).

Eliasson, STIG (2015): "The birth of language ecology: interdisciplinary influences in Einar Haugen's 'The ecology of language”. Language Sciences 50, 78-92.

Gran Diccionari de la Llengua Catalana. Barcelona: Enciclopèdia Catalana, 1998 (esmentat com GDLC).

Grice, H. PAUL (1975): "Logic and conversation". Cole, P.; Morgan, J. L. (eds.): Syntax and Semantics 3. Speech Acts. New York: Academic Press, 41-5 (trad. esp.: "Lógica y conversación”. Valdés, L. Ml. (ed.): La búsqueda del significado. Tecnos - Universidad de Murcia, 1991, 511-530).

Halliday, M. A. K. (1978): Language as Social Semiotics. The social interpretation of language and meaning. London: Edward Arnold (trad. esp.: El lenguaje como semiótica social. La interpretación social del lenguaje y del significado. México: Fondo de Cultura Económica, 1982]. 
JaKobSon, Roman (1960): "Linguistics and poetics". Sebeok, T. A. (ed.): Style in language. Cambridge, Mass.: M.I.T., 350-377 (trad. cat.: "Lingüística i poètica". Lingüística $i$ poètica $i$ altres assaigs. Barcelona: Edicions 62, 1969, 39-78).

LEeCh, GEOFfrey (1983): Principles of pragmatics. London: Longman.

Llibre d'estil de la Corporació Catalana de Mitjans Audiovisuals. https://www.ccma.cat/llibredestil/index-guia-editorial [Consulta: 2 febrer 2021].

López Guix, Juan G. (2017): "Doce versiones del «Jabberwocky» de Lewis Carroll: una propuesta de valoración poética”. Estudios de Traducción 7, 49-75.

López SAnjú́n, Victoria (2007): "Sublenguajes y lenguas de fines específicos, ¿̇términos equivalentes y diferentes enfoques?”. Odisea 9, 109-121. <https://www. google.com/search?client=firefox-bd\&q=odisea+victoria+lenguajes+especialidad +lenguas> [Consulta: 2 febrer 2021].

Payrató, Llứs (1996): Català col-loquial. Aspectes de l'ús corrent de la llengua catalana. València: Publicacions de la Universitat de València (3a ed.; 1a ed., 1988).

Payrató, Lluís (2010): Pragmàtica, discurs i llengua oral. Introducció a l'anàlisi funcional de textos. Barcelona: Editorial UOC (2a ed.; 1a ed., 2003).

PAYRATó, Lluís (2018): Introducción a la pragmàtica. Una perspectiva sobre el lenguaje en acción. Madrid: Síntesis.

Pérez Saldanya, Manel; Mestre, Rosanna; Sanmartín, Ofèlia (1998): Diccionari de lingüística. València: Colomar Editors.

Popova, Yanna (2002): “The figure in the carpet. Discovery and re-cognition”. Semino, E.; J. Culpeper (ed.): Cognitive Stylistics: Language and Cognition in Text Analysis. Amsterdam: John Benjamins.

Rubio, JaIme (2020): “¿Saben los demás que estoy sonriendo? Así superamos la barrera comunicativa de la mascarilla". El País, Verne, 16 de maig del 2020 <https://verne.elpais.com/verne/2020/o5/13/articulo/1589374407_261002.html> [Consulta: 2 febrer 2021].

Sanjaume, Margarida (dir.) (2019): Llibre d'estil de les lleis $i$ altres textos del Parlament de Catalunya. Parlament de Catalunya.

<https://www.parlament.cat/document/intrade/292654> [Consulta: 2 febrer 2021].

Saville-Troike, Muriel (2002): The Ethnography of Communication. An Introduction. Oxford: Blackwell (3a ed.; 1a ed., 1982).

Schegloff, Emanuel A. (1985): "On some questions and ambiguities in conversation". Atkinson, J. M. (ed.): Structures of Social Action. Cambridge: Cambridge University Press, 28-52.

Sennet, Adam (2016): "Ambiguity". The Stanford Encyclopedia of Philosophy (Spring 2016 Edition). Zalta, E. N. (ed.). <https://plato.stanford.edu/archives/spr2016 /entries/ ambiguity [Consulta: 2 febrer 2021].

Viana, AMAdeu (1998): “Lewis Carroll: Jabberwocky 1998”. Els Marges: revista de llengua i literatura 62, 59-62. <https://www.raco.cat/index.php/Marges /article/view/111285> [Consulta: 2 febrer 2021]. 
Wittgenstein, Ludwig (1953): Philosophical Investigations. New York: Macmillan.

Comunicació, ambiguiitat i variació funcional. Una visió introductòria Lluís Payrató (2021)

Llengua, Societat i Comunicació, núm. $19 \quad$ http://revistes.ub/index.php/LSC

lsc@ub.edu http://creativecommons.org/licenses/by-nc-nd/4.o doi:10.1344/LSC-2021.19.2 